\title{
Improving Self-Supply of Urban Water and Sanitation Projects through Microfinancing in Nigeria
}

\author{
Emma E. Ezenwaji ${ }^{1}$, Everistus U. Anyaeze², Anthony U. Nwafor ${ }^{3}$ \\ ${ }^{1}$ Department of Geography and Meteorology, Nnamdi Azikiwe University, Awka, Nigeria \\ ${ }^{2}$ Department of Environmental Management, Nnamdi Azikiwe University, Awka, Nigeria \\ ${ }^{3}$ Department of Civil Engineering, Federal Polytechnic, Oko, Nigeria \\ Email: emmaezenwaji@gmail.com
}

How to cite this paper: Ezenwaji, E.E., Anyaeze, E.U. and Nwafor, A.U. (2018) Improving Self-Supply of Urban Water and Sanitation Projects through Microfinancing in Nigeria. Journal of Geoscience and Environment Protection, 6, 20-33.

https://doi.org/10.4236/gep.2018.62002

Received: June 16, 2017

Accepted: February 6, 2018

Published: February 9, 2018

Copyright $\odot 2018$ by authors and Scientific Research Publishing Inc. This work is licensed under the Creative Commons Attribution International License (CC BY 4.0).

http://creativecommons.org/licenses/by/4.0/

\begin{abstract}
Most water and sanitation projects in poor neighbourhood of urban Nigeria are executed through self-supply option. This is defined as an incremental improvement of WASH products e.g. water and sanitation structures by a household or small group of households which are financed by their own effort and investment. It is indeed a concept which complements conventional water supply and sanitation funded by government. The aim of this paper is, therefore, to investigate the extent of the use of innovative financing especially group saving approach to improve water and sanitation projects in Awka town, Nigeria. Towards achieving the aim, data were collected through questionnaires which were designed and administered on the respondents between January and April, 2016 and from other secondary sources. Data were analyzed using Principal Component Analysis and Component scores to establish the extent of the use of this option in the 9 component quarters of the town. Result shows that some quarters have perfected using the self-supply option while in others, it is yet to be widely accepted. It is finally recommended among others that the urban water policy as well as urban water safety plan should be revised to include the option as a way of improving domestic water supply and sanitation in the town.
\end{abstract}

\section{Keywords}

Water, Sanitation, Households, Innovative, Self-Supply

\section{Introduction}

The severe water supply shortages and poor provision of sanitation services by 
relevant government levels and agencies especially in poor urban neighbourhoods in Nigeria have provoked households in such neighbourhoods to attempt the provision of the services themselves. These households largely achieve their water supply and sanitation provision through the concept of self-supply. This is the development or improvement of water supplies by households largely or wholly at their own cost. This approach has helped to increase coverage in the sector where it is not feasible or cost effective to develop communal supplies by government. Self-supply can also supplement existing services by improving water quality, quantity reliability and access. Despite its potential for expanding service especially to the unserved, self-supply is often not formally recognized as a model of service delivery in sector policy and institutions [1]. In the water supply subsector such areas as rainwater harvesting, construction and upgrading of shallow wells and household water treatment all lead themselves to household investment, while in the sanitation subsector, construction of pit and VIP latrines, construction and installation of wastes collection bins, installation of water closets and construction of associated soak-away pits can easily be handled using the self-supply arrangement.

Self-supply in WASH Products-water supply and sanitation has been developed to a considerable degree in some African countries. In Sierra Leone, [2] outlined the findings of an independent evaluation of two projects in Sierra Leone namely: i) appropriate and innovative WASH self-supply technologies implemented by Welthungerhilfe and ii) the development of a strategy to accelerate household investment in improved water self-supply implemented by Water Aid. The findings presented, demonstrate among others that a formal support to self-supply although a new approach in Sierra Leone is taking root and further it is noted that positive lessons learnt can be taken from the inception of Community Led Total Sanitation (CLTS) the sanitation part of self-supply which was successfully implemented in several communities of Africa in the past years. In Ghana an estimated $14 \%$ of rural water supply coverage is from private or self-supply [3]. In Senegal public water supply operates only 10\% capacity. The consumers and the gap are filled by self-service because the public supply system duplicates service from existing self-supply; much investment may have been wasted and sustainability threatened. In Mali, self-supply has made significant contribution to water provision as over 200 self-supply wells are in used in many urban communities. In East Africa countries, the use of self-supply for WASH is widespread. For example in Zambia as a result of piloting by Blair Institute and Ministry of Health in the early 1990s, Ministry of Water Development recognized the strategy and its contribution to MDGs and so supported family upgrading In Ethiopia water supply and sanitation have improved through selfsupply. [4] outlined approaches for professionalization and promoting of selfsupply in Malawi where the strategy is undergoing rapid development.

In Nigeria only two known studies have been directed to self-supply of WASH products. They are those of [5], who studied self-supply of water in Abeokuta, 
Ogun State. Their study was devoted essentially to urban hand dug wells and it detailed the inventory, classifications and types of wells. The paper further describes the forms of access to dug wells and estimates the number of users and concluded that self-supply plays an essential role in urban water delivery in that the number of users with the access to urban self-supply wells is large enough to mainstream the systems in urban water supply management. In their own part, [6] investigated self-supply as a traditional model for the improvement of water supply in Onitsha Nigeria. These two attempts at revealing the potentials of self-supply options in Nigeria unfortunately did not include the sanitation component as well as how the option could be financed in view of poor government funding to the sector that has made the achievement of sustainability difficult. In 2016 , it was regrettable that Nigeria had a total budgetary allocation of $\$ 53.3$ billion to water supply which is a very poor percentage of the overall budget. The State annual budget allocation for water range from $4.8 \%$ to $9.9 \%$ while that of sanitation from $0.7 \%$ to $3.1 \%$. It is based on the above that this paper is aimed at examining self-supply of urban water supply and sanitation projects in Awka Town and how it can be funded through microfinance method as a way of solving the inadequate funding of the sector from government and donor agencies.

\section{Materials and Method}

\subsection{Area of Study}

Awka urban area is located between Latitude $6^{\circ} 10^{\prime} \mathrm{N}$ and $6^{\circ} 17^{\prime} \mathrm{N}$ and Longitudes $7^{\circ} 00^{\prime} \mathrm{E}$ and $7^{\circ} 10^{\prime} \mathrm{E}$ (Figure 1).

It is the capital of Anambra State, Nigeria, and situated in the tropical high forest area although urbanization and other human activities have relatively disturbed this vegetation leaving outlines of grassland area. The climate is characterized by wet and dry seasons with wet season lasting about 8 months (March to October), while dry season dominate the remaining four months (November to February). In terms of topography, Awka is situated at attitude of about $350 \mathrm{~m}$ above sea level on the Awka-Orlu upland found in the great Mamu River plain. The town has two major ridges located on top of the upland running in a North-South direction, with one in the eastern and other western axis of the town forming its major relief features. The peak of the eastern ridge varies between 300 and $350 \mathrm{~m}$ around Nkwelle-Awka and towards Isiagu community. The lower western ridge is above $150 \mathrm{~m}$ above sea level at Okpuno towards Enugwu-Agidi and Enugwu-Ukwu. In between these two ridges is a trough where the town began and drained by Obizi and Obibia.

Geologically, Awka is underlain by the Imo Shale and Eocene Ameki formation.

The Imo Shale is dominated by low permeability mudstones. In places where there are fingers of sandy units such as the Ifite-Awka sand and Ebenebe sandstone members, the Imo Shale may be seen as a local confinement for the aquifers. According to [7] and [8], in such areas aquifer depths are usually in the 


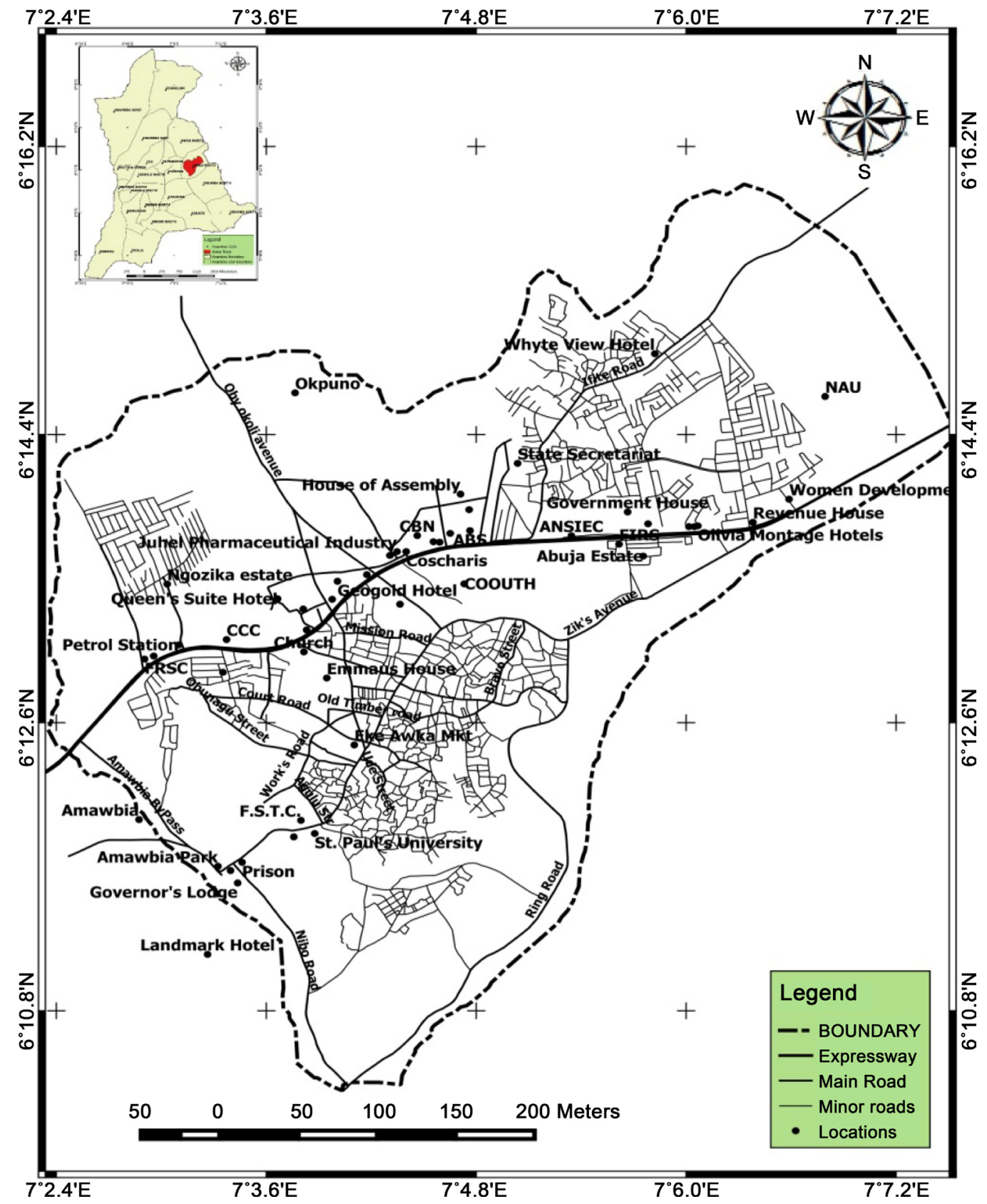

Figure 1. Map of Awka urban area.

range of $20 \mathrm{~m}$ to $60 \mathrm{~m}$ with uncertainty of their capacity to yield water in satisfactory quantity. The Ajalli sandstone can penetrate at about $500 \mathrm{~m}$ beneath Imo shale and constitutes the deep aquifer system capable of sustainable water production.

In parts of Awka where there are outcrops of Ameki/Nanka sands, its depth to exploitable aquifer may range 6.00 to $35.00 \mathrm{~min}$ their shallowest area and may exceed $168 \mathrm{~m}$ in the deepest area. Awka is therefore, hydro-geologically configured into multi aquifer system. Most parts of southern parts of the town around Nkwelle to Isiagu community with the dominance of Imo Shale hinder to a con- 
siderable extent the digging of wells. In parts of Agu-Awka and those of Ifite this formation dominates. However, major parts of the town are underlain by Ajalli formation with productive aquifer that gives the platform for the digging of wells. Awka boasts of many shallow wells that are used mainly by households for their domestic water needs.

\subsection{Data Collection}

Data were collected from households in the nine major residential areas of Awka namely: Amachalla naato, Amikwo, Agulu, Ayomna Okpala, Ezi Awka, Ifite, Ngozika I \& II, Nkwelle, Udoka I \& II from January-April, 2016 with the use of questionnaire. From preliminary assessment of the size of household we found that on average the town has a household population of 6 . The questionnaire was structured in such a way and manner that the respondents could give the information required. As a result of large number of members of household, it would not be feasible to carry out the survey using all, but a sample of them. Consequently, stratified sampling technique was employed in which each residential area formed a stratum and upon which random sampling was employed to select households to administer the questionnaire. In each household, the head of that household was served the questionnaire (Table 1).

However, to determine the sample size for the work, TaroYamene formula was employed which has the formula

$$
n=N /\left[1+\left(N e^{2}\right)\right]
$$

where $n=$ Sample size

$$
\begin{aligned}
& N=\text { total population } \\
& \begin{aligned}
(e) & =\text { tolerable error } \\
N & =84,000, e=0.05 \\
& =84000 /\left[1+\left(84000 \times 0.05^{2}\right)\right]=398
\end{aligned}
\end{aligned}
$$

Table 1. The number and sizes of households from each of the residential districts.

\begin{tabular}{ccccc}
\hline S/No. & $\begin{array}{c}\text { Name of } \\
\text { Residential Area }\end{array}$ & $\begin{array}{c}\text { Number of } \\
\text { Households }\end{array}$ & $\begin{array}{c}\text { Average size of } \\
\text { Households }\end{array}$ & Total Population \\
\hline 1. & Agulu & 12,289 & 7 & 86,023 \\
2. & Amikwo & 10,620 & 7 & 74,340 \\
3. & AwkaGRA/Ahocol & 6202 & 5 & 31,010 \\
4. & Amaenyi & 10,592 & 7 & 74,144 \\
5. & Ezi-Awka & 10,264 & 7 & 71,848 \\
6. & Ifite & 9420 & 6 & 56,520 \\
7. & Ngozika I \& II & 8270 & 5 & 41,350 \\
8. & Udoka I \& II & 8343 & 4 & 33,372 \\
9. & Nkwelle & 8000 & 6 & 48,000 \\
& Total/Mean & $\mathbf{8 4 , 0 0 0}$ & $\mathbf{6}$ & $\mathbf{5 1 7 , 0 0 7}$ \\
\hline
\end{tabular}


This 398 was then distributed according to the Household strength of each district after which the questionnaire was distributed.

\subsection{Data Analysis}

Statistical techniques were employed in the analysis of data and they are Principal Component Analysis (PCA) that produced Principal Component Scores. [9] is of the view that (PCA) is a data reduction statistical technique. It provides a way of collapsing or rearranging a large body of data into fewer, more homogenous groups or sets, each group defining the underlying dimension. The analysis was performed with the aid of the statistical package for the social sciences (SPSS)

The description of the variables and the result of field data are presented in Table 2 and Table 3.

\section{Result and Discussion}

The relationship between the eighteen factors associated with the level of selfsupply and its funding was established using Pearson's Product Moment Corre-

Table 2. Factors affecting self-supply of WASH products and local funding sources in Awka urban area.

\begin{tabular}{|c|c|c|c|}
\hline S/No. & $\begin{array}{c}\text { Variable } \\
\text { Label }\end{array}$ & $\begin{array}{c}\text { Variable } \\
\text { Code }\end{array}$ & Variable Description \\
\hline 1 & TOTAL & $\mathrm{X}_{1}$ & Total number of new wells in the area \\
\hline 2 & POOR & $\mathrm{X}_{2}$ & Number of wells with poor water quality \\
\hline 3 & OWN & $\mathrm{X}_{3}$ & Number of households owning well \\
\hline 4 & MAIN & $\mathrm{X}_{4}$ & Number of wells that are properly maintained \\
\hline 5 & $\mathrm{COV}$ & $\mathrm{X}_{5}$ & Number of wells with cover or apron \\
\hline 6 & PIT & $\mathrm{X}_{6}$ & Number of pit latrines contracted in the district \\
\hline 7 & VIP & $\mathrm{X}_{7}$ & Number of VIP latrines and WCs in the district \\
\hline 8 & SOAK & $\mathrm{X}_{8}$ & Number of soak-away pits constructed in the district \\
\hline 9 & REFU & $\mathrm{X}_{9}$ & Number of refuse bins procured in the district \\
\hline 10 & MET & $\mathrm{X}_{10}$ & Method of funding water and sanitation projects \\
\hline 11 & LOCAL & $\mathrm{X}_{11}$ & If through local funding method which specific type do you use? \\
\hline 12 & COLLA & $\mathrm{X}_{12}$ & Is there any collateral involved? \\
\hline 13 & TYPE & $\mathrm{X}_{13}$ & If 12 is yes, then what type, social, economic or joint collatera? \\
\hline 14 & LOAN & $\mathrm{X}_{14}$ & Whether or not loans are repaid \\
\hline 15 & TIME & $\mathrm{X}_{15}$ & If 14 is yes are they repaid on time or not \\
\hline 16 & REAS & $\mathrm{X}_{16}$ & If not what do you think is the reason \\
\hline 17 & SUST & $\mathrm{X}_{17}$ & Whether or not the funds are used to sustain the WASH products \\
\hline 18 & CLTS & $\mathrm{X}_{18}$ & Whether or not CLTS is operated in the community \\
\hline
\end{tabular}


Table 3. Field data of self-supply and local funding of WASH in Awka.

\begin{tabular}{ccccccccccccccccccccc}
\hline S/N & Residential Area & $\mathrm{X}_{1}$ & $\mathrm{X}_{2}$ & $\mathrm{X}_{3}$ & $\mathrm{X}_{4}$ & $\mathrm{X}_{5}$ & $\mathrm{X}_{6}$ & $\mathrm{X}_{7}$ & $\mathrm{X}_{8}$ & $\mathrm{X}_{9}$ & $\mathrm{X}_{10}$ & $\mathrm{X}_{11}$ & $\mathrm{X}_{12}$ & $\mathrm{X}_{13}$ & $\mathrm{X}_{14}$ & $\mathrm{X}_{15}$ & $\mathrm{X}_{16}$ & $\mathrm{X}_{17}$ & $\mathrm{X}_{18}$ \\
\hline 1 & Amachallana Ato & 218 & 54 & 5214 & 4180 & 180 & 506 & 5422 & 5200 & 400 & 1 & 1 & 1 & 3 & 1 & 0 & 2 & 1 & 1 \\
2 & Amikwo & 212 & 39 & 8212 & 4197 & 197 & 645 & 9900 & 9100 & 840 & 1 & 1 & 1 & 3 & 0 & 0 & 2 & 2 & 1 \\
3 & Agulu & 367 & 68 & 10,360 & 6360 & 359 & 820 & 11,020 & 10,600 & 620 & 2 & 1 & 1 & 3 & 1 & 0 & 2 & 1 & 1 \\
4 & Ayomna Okpala & 115 & 30 & 9060 & 7114 & 115 & 958 & 9300 & 9240 & 486 & 2 & 1 & 1 & 3 & 0 & 1 & 2 & 1 & 1 \\
5 & Ezi-Awka & 198 & 36 & 3194 & 1192 & 193 & 6288 & 3600 & 3500 & 290 & 1 & 2 & 1 & 2 & 0 & 1 & 2 & 2 & 1 \\
6 & Ifite & 108 & 21 & 2070 & 1106 & 108 & 6851 & 2056 & 2050 & 388 & 1 & 2 & 1 & 3 & 0 & 0 & 2 & 1 & 1 \\
7 & Ngozika I \& II & 126 & 24 & 8200 & 6117 & 126 & 10 & 8260 & 8256 & 600 & 1 & 1 & 1 & 2 & 1 & 1 & 2 & 2 & 1 \\
8 & Nkwelle & 89 & 14 & 7110 & 6800 & 89 & 647 & 7200 & 7194 & 269 & 2 & 2 & 1 & 3 & 1 & 1 & 2 & 1 & 1 \\
9 & Udoka I \& II & 109 & 18 & 8310 & 7980 & 109 & 0 & 8340 & 8332 & 800 & 1 & 1 & 1 & 2 & 1 & 1 & 2 & 1 & 1 \\
\hline
\end{tabular}

lation technique. The result (not presented here) reveals serial autocorrelation as many factors showed strong and significant correlation with each other. Since some of these interrelationships are too strong they left us with no other option than to subject the field data to PCA in order to have a parsimonious number of clearly defined orthogonal factors that can explain the variations in the observed data matrix. When PCA was performed with varimax rotation and the Kaiser equalization, five components (eigenvectors) were extracted. These five components shown in Table 4 account for $92.8 \%$ of improvement in self-supply of water and sanitation in Awka through micro-financing of the projects.

From Table 4, it can be seen that Component I has high positive significant loadings on $\mathrm{X}_{2}$ (Poor), $\mathrm{X}_{4}$ (MAIN), $\mathrm{X}_{5}$ (COVE), $\mathrm{X}_{6}$ (PIT), $\mathrm{X}_{7}$ (VIP), $\mathrm{X}_{8}$ (SOAK), $\mathrm{X}_{9}$ (REFU), $\mathrm{X}_{18}$ (CLTS). This component has an eigenvalue of 6.40 and explains $40.20 \%$ of the variation in data. It is indicative of status of the water supply and sanitation in Awka. Furthermore, Component II which accounts for additional $26.30 \%$ of variation with an eigenvalue of 4.18 has positive loadings on $X_{10}$ (MET), $\mathrm{X}_{11}$ (LOCAL), $\mathrm{X}_{13}$ (TYPE), $\mathrm{X}_{14}$ (LOAN), $\mathrm{X}_{17}$ (SUST). This describes the level of local funding of water supply and sanitation in Awka. Components I and II account for $66.50 \%$ of water supply and sanitation improvement in Awka. Component III has positive loadings on two variables $\mathrm{X}_{1}$ (TOTAL), $\mathrm{X}_{2}(\mathrm{OWN})$ and contributes $15.00 \%$ to improvement in WASH in the town with the eigenvalue of 2.14. It is indicative of the high household ownership of wells in the town. Again Component IV has high loading only on one variable $\mathrm{X}_{15}$ (TIME). It contributes $8.20 \%$ to the improvement of WASH in Awka and has an eigenvalue of 1.80. It is indicative of the effects of local funds in the sustainability of WASH in the town. Finally, Component $\mathrm{V}$ loads highly in $\mathrm{X}_{16}$ (REAS) and describes the poor repayment of loans. It has however, an eigenvalue of 1.43 .

\section{The Principal Component Scores}

Principal Component Score was employed to calculate the individual contribution of the original variables for each observation (in our own case each residential are) to the variance explained by each component. They are calculated 
Table 4. Varimax rotated component matrix of factors associated with the Improvement of self-supply of urban water and sanitation through micro-financing.

\begin{tabular}{|c|c|c|c|c|c|c|}
\hline \multirow{2}{*}{\multicolumn{2}{|c|}{ Variables }} & \multicolumn{5}{|c|}{ Components } \\
\hline & & \multirow{2}{*}{$\begin{array}{c}\text { I } \\
0.002\end{array}$} & \multirow{2}{*}{$\begin{array}{c}\text { II } \\
0.001\end{array}$} & \multirow{2}{*}{$\begin{array}{c}\text { III } \\
0.780^{*}\end{array}$} & \multirow{2}{*}{$\begin{array}{c}\text { IV } \\
0.003\end{array}$} & \multirow{2}{*}{$\frac{\mathrm{V}}{0.180}$} \\
\hline $\mathrm{X}_{1}$ & TOTAL & & & & & \\
\hline $\mathrm{X}_{2}$ & POOR & $0.716^{*}$ & -0.125 & 0.462 & 0.390 & 0.008 \\
\hline $\mathrm{X}_{3}$ & OWN & 0.005 & 0.163 & $0.895^{*}$ & 0.167 & 0.151 \\
\hline $\mathrm{X}_{4}$ & MAIN & $0.849^{*}$ & 0.272 & 0.006 & 0.421 & 0.283 \\
\hline $\mathrm{X}_{5}$ & COVER & $0.810^{*}$ & -0.180 & 0.120 & 0.430 & 0.238 \\
\hline $\mathrm{X}_{6}$ & PIT & $0.892^{*}$ & 0.120 & 0.008 & 0.200 & 0.132 \\
\hline $\mathrm{X}_{7}$ & VIP & $0.894^{*}$ & 0.003 & 0.115 & 0.006 & 0.000 \\
\hline $\mathrm{X}_{8}$ & SOAK & $0.719^{*}$ & 0.001 & 0.007 & 0.004 & 0.050 \\
\hline $\mathrm{X}_{9}$ & REFU & $0.877^{*}$ & 0.009 & -0.002 & 0.001 & 0.005 \\
\hline $\mathrm{X}_{10}$ & MET & 0.273 & $0.880^{*}$ & 0.004 & 0.316 & 0.460 \\
\hline $\mathrm{X}_{11}$ & LOCAL & -0.194 & $0.885^{*}$ & 0.007 & 0.399 & 0.230 \\
\hline $\mathrm{X}_{12}$ & COLLA & 0.104 & $0.774^{*}$ & 0.002 & 0.004 & 0.007 \\
\hline $\mathrm{X}_{13}$ & TYPE & 0.280 & $0.732^{*}$ & 0.417 & 0.0242 & 0.001 \\
\hline $\mathrm{X}_{14}$ & LOAN & 0.012 & $0.880^{*}$ & 0.430 & 0.238 & 0.515 \\
\hline $\mathrm{X}_{15}$ & TIME & 0.003 & 0.591 & 0.140 & $0.899^{*}$ & 0.000 \\
\hline $\mathrm{X}_{16}$ & REAS & 0.200 & 0.574 & 0.418 & 0.396 & $0.795^{*}$ \\
\hline $\mathrm{X}_{17}$ & SUST & 0.186 & $0.780^{*}$ & 0.000 & 0.168 & 0.154 \\
\hline \multirow[t]{4}{*}{$\mathrm{X}_{18}$} & CLTS & $0.726^{*}$ & 0.341 & 0.414 & 0.144 & 0.120 \\
\hline & Eigen values & 6.40 & 4.18 & 2.14 & 1.80 & 1.43 \\
\hline & $\%$ Explained & 40.20 & 26.30 & 15.00 & 8.20 & 3.10 \\
\hline & Cum \% & 40.20 & 66.50 & 81.5 & 89.79 & 92.8 \\
\hline
\end{tabular}

*Significant loadings are \pm 0.700 and above.

with the equation:

$$
\operatorname{Csik} \sum_{j=1}^{n} \text { Dijhjk }
$$

where $C s i k$ is the score of the observation $i$ on component $k$,

$D i j$ is the standardized value for variable $j$ on each residential district;

$C j k$ is the loading of the variable $j$ on component $k$. Summation is over all the variables.

Based on the above, the component scores of financial water supply and sanitation characteristics of 9 residential areas of Awka as presented in Table 5 is based on two most important components I \& II, namely; the status of WASH and Level of funding of WASH. The result is presented in Table 5.

From the Table component I, Status of WASH exhibits its lowest effect in Amachalla na Ato (-6.66). The conclusion is therefore, that WASH has the low- 
Table 5. Component scores of component I \& II.

\begin{tabular}{cccc}
\hline \multirow{2}{*}{ S/No. } & Residential Area & I & II \\
\cline { 3 - 4 } & Amachallana Ato & -6.66 & -5.42 \\
1 & Amikwo & -5.19 & -2.78 \\
2 & Agulu & -3.62 & -1.65 \\
3 & Ayomna Okpala & -1.45 & -1.70 \\
4 & Ezi-Awka & -0.64 & -0.52 \\
5 & Ifite & 0.84 & 0.52 \\
7 & Ngozika I \& II & 3.91 & 1.56 \\
8 & Nkwelle & 2.33 & 2.86 \\
9 & Udoka I \& II & 7.78 & 4.39 \\
\hline
\end{tabular}

est performance in the residential area followed by Amikwo (-5.19) and Agulu (-3.62) and highest is Udoka (7.78) and Ngozika (3.91) followed by Nkwelle (2.33). If the level of WASH funding (Component II) is considered then the same disposition is seen where Amachalla na Ato $(-5.42)$ is the lowest while Udoka (4.39) is the highest. The areas with high scores are those that are currently exploiting various microfinance opportunities to improve WASH in their area.

\section{Discussions}

From the PCA result of our field data it could be seen that some scenarios have emerged as a result of summarization of our eighteen variables into five and these are;

i) Status of WASH (waster supply and sanitation) in Awka

ii) Level of funding of WASH in Awka

iii) High ownership of wells in Awka

iv) Effects of local funding on WASH in Awka

v) Poor repayment of loans

The fact the components I and II contribute so much to the total variation, they are singled out for discussion.

\section{Status of WASH in Awka}

From all the variables that loaded highly in Component I there is no doubt that many households in the town depend on shallow wells for domestic water supply in the town. In Table 3, 61,730 out of 84,000 households or $73.48 \%$ own their own private well which was confirmed by Component III. Again, it could be seen that an equally high percentage of household struggle to provide their own sanitation requirements. The variables $\mathrm{X}_{6}, \mathrm{X}_{7}, \mathrm{X}_{8}, \mathrm{X}_{9}$, and $\mathrm{X}_{18}$ that exhibited significance in the analysis confirm this claim. For example 61,498 households or $73.21 \%$ have VIP toilets and or WCs and 63,472 or $75.6 \%$ have soak-away pits 
which they constructed with their own money. The acceleration of self-supply WASH in the town is because of the poor services being rendered by the State and urban Local Governments. From the statistics presented in Table 3 there is no doubt that water supply and sanitation is accelerating and expanding in the town through self-supply. Unfortunately, no support organizations involved in improving this model has come to render assistance to households in Awka as in other parts of Africa. In Tanzania according to [4], self-supply services such as SHIPO are instrumental in lifting the quality of products provided for self-supply. Governments' inability to make water and sanitation facilities available for people have no doubt increased the mortality rate in the area from poor quality water consumption and inadequate sanitation facilities. Self-supply can supplement existing services that are unreliable or inadequate for some uses. It can upgrade service in terms of water quality, quantity and access (Table 3). Such improvements may also reduce demand on community service provided by government (Smiths and Sutton, 2015). In Awka, public provision of water and sanitation is experiencing daily difficulty because these public services are poorly maintained and improperly managed and as a result suffer frequent breakdown. In contrast, people who invest in their own water supply as is the case in Awka choose the technology and have vested interest that the services are more likely to develop sustainable systems. Research bears this out: household-managed options tend to outperform commercial options in sustainability and service delivery. In Awka for example 45,046 out 61,730 wells owned by households or $72.9 \%$ are properly managed by April, 2016 as against about $20.6 \%$ of communal and public wells in the area [10]. Furthermore, in Zimbabwe, $88 \%$ of private family wells were working in 2006 versus only $72 \%$ of communal deep wells and boreholes, and in Zambia, Kaoma district WASH committee found that $94 \%$ of the 3640 family wells were functioning in 2001 versus $49 \%$ of 321 communal protected wells [11].

However, [6] found that self-supply of water in Onitsha has improved the condition of wells, mode of operation, reduced pollution of the wells and the associated improvement in the quality of water supplied thus expanding the capacity of water supply in the town to yield better access, reliability and cost effectiveness.

\section{Level of Funding of WASH in the Town}

Lack of adequate water supply and sanitation facilities for the provision of water supply is increasing by the day in Awka despite the funding support from the State Government and donor agencies. Responding to the deterioration in water supply and sanitation performance, the State Government embarked on a series of sector reforms to upgrade the level of service. Important areas of this reform include decentralization of control and deregulation of the operations, organizational restructuring especially to involve private sector and promote community management. Government also embarked on adhoc crash programmes of water provision through the massive albeit indiscriminate siting and 
construction of boreholes. [12] has studied the distribution of such boreholes to ascertain the nature of distribution and found them to be random and therefore fulfilling little promise for many households. According to [13], the EU and the Federal Government of Nigeria agreed in December to support the implementation of Water Supply and Sanitation Reform Programme (WSSSRP) in Nigeria. The reform objectives was to increase access to safe, adequate and sustainable water and sanitation services in six focal States of Nigeria in which Anambra State is one. From the surveys carried in Anambra only $7.2 \%$ of the populace are supplied with water but the situation in Awka is even more worrisome as [14] found that only $2.3 \%$ of the populace of the town benefit from public water supply. This shows that attempts by government to improve these important amenities met with many disappointments as the people continue to experience water scarcity and poor sanitation.

The people in reaction to these endemic problems decided to take their faith in their hands by organizing themselves into local groups capable of raising funds to improve water and sanitation sources. This has enabled them to dig shallow wells, fit them with submersible pumps, provide small generating set and pipe water inside their houses as well as their neighbours in some cases. In some residential districts such as Ngozika, Nkwelle, and Udoka households have organized themselves into Self-Help Groups (SHGs) to embark on microfinance mechanism with which they can borrow funds to dig boreholes or shallow wells, buy pumps and generating sets, as well as, buy and install surface or overhead tank to store water. The methodology embarked by members is that they will agree on collection of an agreed sum of money in the year from members. These are then paid out as loan for one person at a time, repeating the procedure over time until each member is served. According to [15], the evolution of the concept has seen formal Microfinance Institutions (MFI) crafting various adaptations of this methodology to satisfy their client. This method known as ISUSU in Anambra State has provided enough funds to households to construct and maintain water and sanitation facilities. The increasing construction of new VIP latrines as well as retrofication in some households to introduce Water Closet (WC) system are all made possible largely by this local funding system. The beneficiary usually has joint collateral responsibility to pay back loan with interest at the end of the agreed period. Thus, to qualify for the loan, one has to belong to both residential districts and also participate actively.

In a more developed neighbourhood such as Udoka Housing Estate a family that wishes to construct household borehole or well apply for loan from Microfinance Bank located in the area. The Microfinance Bank (MFB) developed financial operational checks to hold households responsible and accountable for the loans in which two existing account holder of the MFB had to guarantee the application for loan. Just in another area of West Africa especially Lome, Togo and Accra in Ghana borrowers had to prove their need for improved water supply systems and demonstrate willingness to pay for water. When approved the 
beneficiary is not paid directly in cash but the MFB directs a company which is its water construction and sanitation partner to construct either the borehole, VIP latrine, purchase of family waste bin etc. and then households directly pay back to MFB with an interest. By, however, ensuring that borrowers are willing to pay for water services MFB received confirmation that its loans would be used to provide a business service. Again, in Nkwelle some age-grades have formed themselves into sanitation co-operative. The program is fashioned in a way that members contribute themselves and also source funds from friends and family members, to open an account with an MFB and the deposit now allows them to draw above the limit of their deposits to members who want to engage in the construction of VIP toilet and who pay the co-operative with only $10 \%$ interest. By this, households improve their water supply and sanitation facilities and at same time increase the financial base of the co-operative.

The residential districts considered here are those who have started improving their WASH services with available local funding (Table 5).

\section{Recommendations}

From the foregoing the following are recommended to ensure the improvement of the model and expansion of water supply and sanitation services.

1) Some operators raise concerns that self-supply do not encourage environmental disturbances. Based on this, it is advised that relevant government agency should guide the construction of boreholes or digging of shallow wells by issuing permit.

2) Current water policy in both Nigeria and individual states should be revised to include self-supply as a relevant alternative in meeting water and sanitation needs of the people especially in water scarce areas.

3) Self-supply is presently competing with conventional water supply. This should not be so because self-supply is only naturally positioned to play a complementary role.

4) All the various microfinance measures for improving WASH in practice in the town should be harmonized into one to enable easy operation.

5) Microfinance Banks involved in provision of loan to households for water supply and sanitation should be meant to charge low interest rates on loans. This is the only way to improve the repayment rates.

6) Again rate of repayment of loans should not be used to measure success of water and sanitation projects. This is because some borrowers may go into debt to repay loans which defeats the purpose of issuing loans to the poor in the first instance.

7) MFBs in addition to granting loans should also offer capacity building programmes to beneficiaries which include the development of their skills and training them to use the loans productively as well as to participate actively in the construction and upkeep of the improved water and sanitation sources.

8) Government should encourage those who have strong Self-Help Groups 
(SHGs) by giving them grant to complete water and sanitation projects after they had raised about $25 \%$ of the cost.

\section{Conclusion}

As could be seen, we have employed the Principal Component Analytical technique to isolate the residential districts (areas) that have developed a microfinance arrangement to improve their WASH products i.e. water supple and sanitation. It could be seen that all residential areas that are in traditional settlement performed poorly while all the areas that have a large percentage of stranger elements perform high. One reason for this is that the traditional settlements are made up very high percentage of natives as against high percentage of settlers in the new Estates. However, in all there is a rising awareness that households should be their own water and sanitation utility companies. The information revealed in Table 2 is very instructive. It is, therefore, very necessary that the urban water policy which presently does not accommodate this innovative funding practice should be revised to ensure that self-supply of WASH products is included in the policy document. This is one way of improving water supply and sanitation in the town.

\section{References}

[1] Smiths, S. and Sutton, S. (2015) Triple-S: Self Supply: The Case for Leveraging Greater Household Investment in Water Supply. Water Africa, 3, 28-36.

[2] Gillard, M. (2014) WASH Self-Supply in Sierra Leone: Perspectives and Options. Water Aid Publication, Free Town.

[3] IRC and Agua Consult (2011) Briefing Note.

[4] Olschewski, A., Van Donk, M. and Maillo, J. (2015) Innovative Mechanisms for Improving Self Supply Services. $38^{\text {th }}$ WEDC International Conference, Loughborough University, July 2015, 64-71.

[5] Oluwasanya, G., Smith, J. and Carter, R. (2011) Self-Supply Systems: Urban dug wells in Abeokuta, Nigeria. Water Science and Technology, 11, 172-178. https://doi.org/10.2166/ws.2011.026

[6] Ezenwaji, E.E. and Eduputa, B.M. (2016) Self Supply as a Traditional Model for the Improvement of Water Supply in Onitsha, Nigeria. $39^{\text {th }}$ WEDC International Conferences, Kumasi, 11-15 July 2016, 81-94.

[7] Reymen, C.O. (1965) Problems of Exploiting Underground Water in Imo Shale Area of Eastern Nigeria. Geological Bulletin, 3, 45-49.

[8] Nwozor, K.K., Chiaghanam, O.I. and Ownurah, L.O. (2015) Borehole Annulus-Filling Materials and Enrichment of Heavy Metals in Eocene-Palacocene Aquifer Systems in AwkaS.E Nigeria. British Journal of Applied Sciences and Technology, 8, 277 -285. https://doi.org/10.9734/BJAST/2015/14955

[9] Anyadike, R.N.C. (2009) Statistical Methods for the Social and Environmental Sciences. Spectrum Books Ltd., Ibadan.

[10] Obiechina, T.N. (2016) Community Choice of Water Supply Source in Parts of Anambra State, Nigeria. Journal of Rural Water Supply, 6, 20-28.

[11] WSP (2004) Rural and Urban Water Supply in East Africa. Voice Master East Af- 
rica, 3, 11-22.

[12] Ezenwaji, E.E. and Okafor, M.M. (2017) Distribution of Shallow Wells in Parts of Awka Metropolis. Journal of Geography and Environment, 1, 18-29.

[13] Olugboye, D. and Hayes, J. (2011) Review of PfWS Technical Support to Anambra State Water Supply and Sanitation Sector Reform Programme in Nigeria. $35^{\text {th }}$ WEDC International Conference, Loughborough.

https://wedc-knowledge.lboro.ac.uk/resources/conference/35/Olugboye-D-1159.pdf

[14] Akabo, M.A. (2016) Urban Water Supply and Government Policy on Social Amenities in Awka Town, Nigeria. Journal of Water and Sanitation, 4, 230-239.

[15] Agbenorheri, M. and Fonesca, C. (2005) Local Financing Mechanisms for Water Supply and Sanitation Investments. IRC International Water and Sanitation Centre, The Hague. 